\title{
CZECH AGRARIAN TRADE COMPARATIVE ADVANTAGES DISTRIBUTION IN RELATION TO DEVELOPED AND DEVELOPING COUNTRIESI
}

\author{
Luboš Smutkal, Mansoor Maitah ${ }^{1}$, Miroslav Svatoš ${ }^{1}$ \\ ${ }^{1}$ Department of Economics, Faculty of Economics and Management, Czech University of Life Sciences Prague, \\ Czech Republic
}

\begin{abstract}
SMUTKA LUBOŠ, MAITAH MANSOOR, SVATOŠ MIROSLAV. 2018. Czech Agrarian Trade Comparative Advantages Distribution in Relation to Developed and Developing Countries. Acta Universitatis Agriculturae et Silviculturae Mendelianae Brunensis, 66(4): 1001-1015.

This article deals with the issues of the current state of commodity structure and distribution of comparative advantages of the Czech agrarian trade in comparison to developed, developing and also in comparison with Commonwealth of Independent States and in relation to other European countries (i.e. non-EU and CIS countries). The goal of this paper is to identify how the comparative advantages of Czech Agrarian exports are distributed. In addition to this, the article also attempts to identify the main differences in the characteristics of agrarian trade between developed countries on one hand and developing countries on the other hand. The results suggest that the agrarian trade performs very differently in relation to individual groups of countries. The Czech agrarian trade has been progressively developing, specifically in relation to developer countries of the world. In this regard, it is necessary to mention the constantly improving characteristics of the Czech agrarian trade in relation to EU28 countries (however, the comparative advantages are based on low prices and high volumes of exported goods. In relation to developing countries, Czech trade is more or less stagnate (however, the trade is based on items with a higher level of processing and in comparison with developed countries is also based on items with significantly higher unit prices). A rather specific development was also recorded in relation to CIS countries and "other European countries". The Czech Republic has a highly competitive commodity structure in relation to these countries, which is primarily based on the export of goods with higher value added and relatively high per kilogram prices.
\end{abstract}

Keywords: Czech agrarian trade, developed countries, developing countries, CIS countries, other European countries, structure, comparative advantages

\section{INTRODUCTION}

Agrarian Foreign Trade of the Czech Republic is undergoing a dynamic transformation (Burianova, 2011; Burianova, 2012). Its value grew from CZK 49 billion to over CZK 201 billion in exports from 2001 to 2016 and from more than CZK 69 billion to more than CZK 224 billion in the case of imports. Within the framework of its own foreign trade activities, the Czech Republic is primarily oriented towards cooperating with the more advanced countries of the world. Within this group of countries, (Basek

1 The distribution of countries into developed and developing countries which has been done according to the methodology of the Czech Statistical Office. For more see the following link: https://www.czso.cz/csu/czso/600107-v_lednu_az_cervenci_2007-seskupeni_zemi 
and Kraus, 2009; Burianova 2011; Burianova and Belova, 2012) it is primarily the EU member states who dominate (These countries, regardless of their own membership in the OECD, participate by about 88\% of the Czech Republic's agricultural trade turnover). The share of agrarian trade in relation to developed countries has been gradually increasing and currently stands at about $84 \%$ of the turnover value. While the Czech Republic's orientation towards developed countries is becoming more and more apparent, the share of developing countries has been steadily decreasing. Currently, these countries account for only $16 \%$ of the turnover value of agrarian trade in the Czech Republic. In general, it is important to note that the Czech agrarian trade is primarily focused on the markets of Europe and, to a certain extent towards the markets of the countries of the former Soviet Union. The share of European countries and CIS member countries in the Czech Republic's agrarian trade turnover currently stands at around 92.4\%. From that, it follows that the share of other, especially non-European territories is very low. Despite the fact that it is mainly the non-European territories, which at the moment represent and will represent in the future, the primary markets of global agrarian and food production. An additional weakness is the extreme territorial concentration of Czech agrarian trade. Only about five countries (Germany, Slovakia, Poland, Austria and Hungary, i.e. closest neighbors) account for about $60 \%$ of the turnover of the total agrarian trade of Czech agrarian trade. This makes the Czech agrarian trade extremely vulnerable (Pohlova and Mezera, 2014). There are several important reasons for this condition, and there are two main causes as well. First, the Czech Republic is a small Central European country that has no direct access to any harbours. Harbour access would allow it to develop trade effectively on an inter-regional basis. The second reason is the EU membership. The Czech Republic is part of the single market of EU countries and its foreign trade policy, as with other countries (Jambor, 2014; Ferto, 2008), is bound to the Common Commercial Policy of EU countries. Another cause of the above mentioned is the commodity structure of Czech agrarian trade, which, especially in the case of exports, is strongly oriented towards goods with a limited rate of processing, low kilogram prices and large volume. Typical examples of Czech agrarian exports are in general: large-scale feed, cereals, oilseeds, mineral water, live animals, fresh milk, etc. It is quite paradoxical that Czech agrarian trade has thrived in recent years, because of its orientation towards goods with low kilogram prices. In the last fifteen years, cheap production has ensured a very strong growth dynamic of mainly exports. Their value is growing not because of rising unit export prices, but primarily because of the growing volume of exported goods. From this point of view, it is interesting to see how their own commodity structure is profiled in the Czech agrarian trade and also in its comparative advantages. However, it is also important to mention that Czech agrarian trade is of a dual nature. If we want to understand its development and its structure, it is necessary to evaluate it in the internal dimension of EU trade as well as with non-EU countries. (Kancs and Ciaian, 2010; Presa et al., 2008; Smutka et al., 2015). Many articles and contributions have elaborated on this topic in the past, and discovered numerous findings. These findings generally correspond to one general fact. That fact is that with the accession into the EU, the Czech Republic has reduced its orientation towards third countries. Furthermore the Czech agrarian trade has been significantly affected by competition in addition to investments originating in the EU (Svatos, 2008; Vozarova et al., 2015; Svatos et al., 2013). While the weakness of Czech agrarian trade is its long-term inability to concentrate more on goods with a higher degree of processing and higher added value. The article differs from the cliché mentioned above and attempts to offer a slightly different view of the Czech agrarian trade in the following dimension: where on one hand the agrarian trade is analyzed in relation to developed countries (according to the CZSO methodology) and on the other hand the trade is analyzed in relation to developing countries. The commodity structure of agrarian trade, and in particular the distribution of comparative advantages, is analyzed precisely in relation to these two groups of countries. In addition, our own analysis also contains an analysis of the commodity structure and the distribution of comparative advantages in relation to two relatively neglected groups of countries, such as the other European countries (without EU and CIS member countries) and the CIS member states (i.e. the former USSR - again according to the CZSO methodology ).

\section{MATERIALS AND METHODS}

The objective of this article is to identify the main characteristics of commodity structure of the Czech agrarian trade in relation to four groups of countries (developed countries, developing countries, CIS countries and other European countries (i.e. excluding EU28 and former USSR countries). The second goal is to identify how the comparative advantages of the Czech agrarian trade are distributed in relation to the above mentioned groups of countries. Last but not least, the article aims to identify the main differences in the nature of the agrarian trade in comparison to developed countries, as well as developing countries. It is the need for a deeper understanding of the situation in relation to developing countries, which can be key for the future development of the Czech agrarian trade, especially given the situation of global markets. It is the developing countries, which appear to be the real future market of agrarian and food production. This is due to the dynamically increasing demand in these 
countries, which is powered by population increases and increases in economic and purchasing power of developing regions and regions in transition.

The commodity structure (we applied the CN system ${ }^{2}$ of dividing agrarian trade into 24 commodity groups) is analyzed primarily in relation to added value development and distribution. The mentioned commodity structure system is applied because of the ease result interpretation and because of data availability. Data sources for individual analyses are the following: UN COMTRADE, and The Czech Statistical Office. Collected data encompasses the following categories: export and import value and volume, and the unit value of realized exports and imports. The paper analyzes through the use of basic statistical indicators and general development trends of export and import value and volume. The other analyzed categories are export/import coverage ratio, and export and import unit value development. An important part of the analysis is related to the problem of comparative advantages distribution. The ambition of the paper is to specify the main driver of Czech agrarian trade value development. In this case, the paper specifies whether the main driving force of Czech agrarian trade value is unit value of traded products or volume performance. The analyses is performed in relation to the above specified group of countries representing trade partners of the Czech Republic. As it was mentioned previously, we applied several different types of indices to measure the level of Czech agrarian trade comparative advantage. The basic indicator applied to discover the real state of Czech agrarian trade comparative advantages distribution is the standard RCA index (proposed by Balassa, 1965; 1977).

RCAij $=((X i j-M i j) / \Sigma i(X i j+M i j)) /((\Sigma j$ Xij $-\Sigma \mathrm{j} \mathrm{Mij}) /(\Sigma \mathrm{i} \mathrm{Xij}+\Sigma \mathrm{j} \mathrm{Mij}))$

Where Xij and Mij represent country i's export and import of product j. RCAij $>1$ indicates that country $i$ has a comparative advantage in the production of $\mathrm{j}$; the greater the index, the stronger the advantage. RCAij $<1$ indicates that country $i$ has a comparative disadvantage in the production of $\mathrm{j}$; the smaller the index, the greater the disadvantage. The advantage of the RCA index is its ability to identify comparative advantages/disadvantages that exist generally. However, it is not able to identify the partial comparative advantages that only exist at the bilateral level. To be able to identify those existing comparative advantages we decided to apply a different index.

For this index we used the Lafay index (Lafay, 1992). Using this index, we considered the difference between each item's normalized trade balance and the overall normalized trade balance. Unlike the above indexes, The Lafay index does not take into account world variables. Using the LFI index, we can focus on bilateral trade relations between countries and regions. Moreover, this index is more reliable in regards to the over-time comparison of sectors within a country. The Lafay index helps us to understand the comparative advantages over time and to compare the strength of comparative advantages of individual products and product groups, for individual regions and countries. For a given country, $i$, and for any given product $j$, the Lafay index is defined as:

$$
L F I_{j}^{i}=100\left(\frac{x_{j}^{i}-m_{j}^{i}}{x_{j}^{i}+m_{j}^{i}}-\frac{\sum_{j=1}^{N}\left(x_{j}^{i}-m_{j}^{i}\right)}{\sum_{j=1}^{N} x_{j}^{i}+m_{j}^{i}}\right) \frac{x_{j}^{i}+m_{j}^{i}}{\sum_{l=1}^{N} x_{j}^{i}+m_{j}^{i}}
$$

Where $x_{j}^{i}$ and $m_{j}^{i}$ are exports and imports of product $j$ of country $i$, towards and from the particular region or the rest of the world, respectively, and $N$ is the number of items. Positive values of the Lafay index indicate the existence of comparative advantages in a given item; the larger the value, the higher the degree of specialization. (Zaghini, 2003). The next part of the analysis presented in this paper was conducted using the analytical tool, called "Products Mapping". This tool allows the user to assess leading exported products from two different points of view, i.e. domestic trade-balance and international competitiveness. (Widodo, 2009). The Product Mapping approach is based on the application of

2 CNO1 Live animals, CNO2 Meat and edible meat offal, CN03 Fish and crustaceans, molluscs and other aquatic invertebrates, CN04 Dairy produce birds' eggs natural honey edible products of animal origin, not elsewhere specified or included, CN05 Products of animal origin, not elsewhere specified or included, CN06 Live trees and other plants bulbs, roots and the like cut flowers and ornamental foliage, CN07 Edible vegetables and certain roots and tubers, CN07 Edible vegetables and certain roots and tubers, CN08 Edible fruit and nuts peel of citrus fruit or melons, CN09 Coffee, tea, mate and spices, CN10 Cereals, CN11 Products of the milling industry malt starches inulin wheat gluten, CN12 Oil seeds and oleaginous fruits miscellaneous grains, seeds and fruit industrial or medicinal plants and fodder, CN13 Lac gums, resins and other vegetable saps and extracts, CN14 Vegetable plaiting materials vegetable products not elsewhere specified or included, CN15 Animal or vegetable fats and oils and their cleavage products prepared edible fats animal or vegetable waxes, CN16 Preparations of meat, of fish or of crustaceans, molluscs or other aquatic invertebrates, CN17 Sugars and sugar confectionery, CN18 Cocoa and cocoa preparations, CN19 Preparations of cereals, flour, starch or milk pastry cooks' products, CN20 Preparations of vegetables, fruit, nuts or other parts of plants, CN21 Miscellaneous edible preparations, CN22 Beverages, spirits and vinegar, CN23 Residues and waste from the food industries prepared animal fodder, CN24 Tobacco and manufactured tobacco substitutes 
two different indices: The LFI index and The TBI index. Trade Balance Index (TBI) is employed to analyze whether a country has a specialization in exporting (as net-exporter) or in importing (as net-importer) for a specific group of products. TBI is simply formulated as follows:

$$
T B I_{i j}=\left(x_{j}-m_{j}\right)\left(x_{j}+m_{j}\right)
$$

Where TBIij denotes the trade balance index of country $i$ for product $j ; x_{i j}$ and $m_{i j}$ represent exports and imports of a group of products $j$ by country $i$, respectively (Lafay, 1992). A country is referred to as "net-importer" in a specific group of products if the value of TBI is negative, and as "net-exporter" if the value of TBI is positive. (Widodo, 2009)

Tab. I represents a matrix for the distribution of the entire set of exported products into 4 groups according to the two selected indicators (LFI and TBI). LFI index has been chosen for the "product mapping" approach, because of its ability to take into consideration only those transactions which are really related to individual countries' trade performance (in this case the Czech Republic's trade performance). The TBI index is applied for

I: Product mapping (proposed by Widodo, 2009 and modified by Smutka et al., 2015)

\begin{tabular}{|c|c|c|c|}
\hline \multirow{2}{*}{ Lafay index } & LFI $>0$ & $\begin{array}{c}\text { Group B: } \\
\text { Comparative Advantage } \\
\text { Net-importer } \\
(\text { LFI }>0 \text { and TBI }<0)\end{array}$ & $\begin{array}{c}\text { Group A: } \\
\text { Comparative Advantage } \\
\text { Net-exporter } \\
(\text { LFI }>0 \text { and TBI }>0)\end{array}$ \\
\hline & $\mathrm{LFI}<0$ & $\begin{array}{c}\text { Group D: } \\
\text { Comparative disadvantage } \\
\text { Net-importer } \\
(\text { LFI }<0 \text { and TBI }<0)\end{array}$ & $\begin{array}{c}\text { Group C: } \\
\text { Comparative disadvantage } \\
\text { Net-exporter } \\
(\text { LFI }<0 \text { and TBI }>0)\end{array}$ \\
\hline \multirow{2}{*}{\multicolumn{2}{|c|}{ Czech Agrarian Foreign Trade Commodity Structure }} & $\mathrm{TBI}<0$ & $\mathrm{TBI}>0$ \\
\hline & & \multicolumn{2}{|c|}{ Trade Balance Index } \\
\hline
\end{tabular}

Source: own modification and processing (2017)

II: Basic overview of Czech agrarian trade development in 2001-2016 (ths. CZK) + Unit price + inter annual growth rate

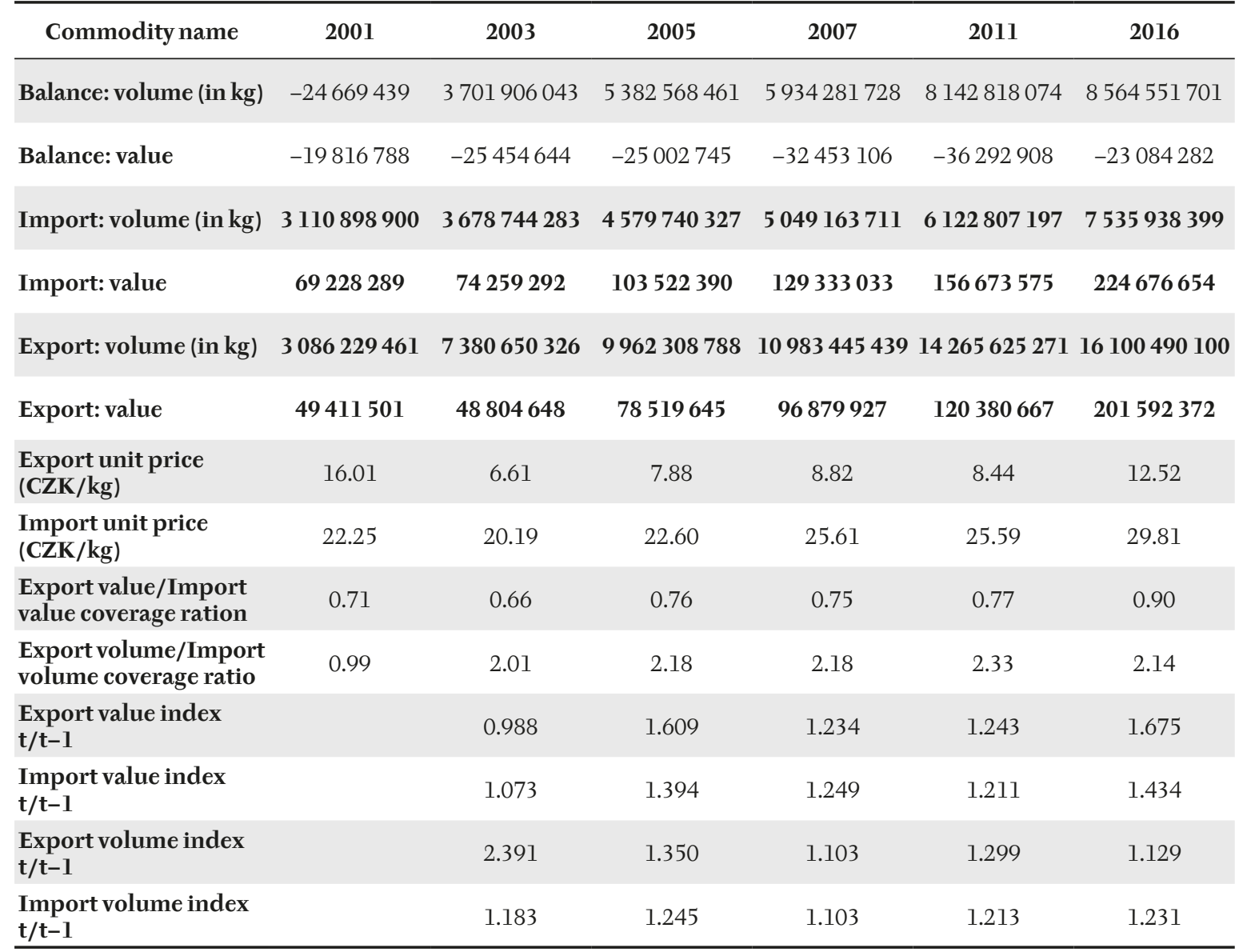

Source: CZSO (2017) 
its ability to divide the products according to their real trade performance into the above specified four quadrants. The chosen approach provides the ability to specify the comparative advantages on the basis of real bilateral trade performance (in relation to the selected group of partners).

\section{RESULTS}

\section{Commodity structure changes in agrarian foreign trade of the Czech Republic}

As it was previously mentioned, the Czech agrarian trade has in recent years significantly increased its value and volume of trade goods. The breaking point in the development of the value and structure of foreign trade was in the years from 2003 to 2005. During this period, the Czech agrarian trade resurrected itself and evolved into the next phase of development. During the period before the EU accession, the Czech agrarian trade was stagnate. The growth dynamics import value exceeded exports and it resulted in a steadily increasing negative balance of the agrarian trade. After the EU accession, this trend reversed. The growth dynamics of value of exports exceeded the growth dynamics of value of imports and even the negative balance of the Czech agrarian trade stabilized.

In the period after entrance into the EU, it became possible to significantly strengthen export activities, mainly in relation to developed countries and within that category, mainly in relation to member countries of the EU. On the other hand, in relation to developing countries and generally non-member countries of EU, trade was stagnant. Nonetheless this decrease was more than compensated through accession to the market in relation to the "old member countries of the EU", but also in relation to the "new member countries of the EU". The weakness of the increase in the value of trade which followed was the extreme orientation of the Czech agrarian trade that was primarily directed towards items with lower degree of processing and low per kilogram prices in comparison with imports coming into the Czech Republic (detail overview of the development of the Czech agrarian trade in period 2001-2016 can be found in Tab. II).

In the monitored period, the growth of mass contributed to the increase in Czech agrarian exports by more than ninety percent. Furthermore, if we were to compare the coverage of imports

III: Czech Agrarian Trade-LFI, RCA, TBI index (value)

\begin{tabular}{|c|c|c|c|c|c|c|c|c|c|}
\hline \multirow{2}{*}{$\begin{array}{l}\text { Commodity } \\
\text { code }\end{array}$} & \multicolumn{3}{|c|}{ LFI (Bilateral) } & \multicolumn{3}{|c|}{ RCA (World) } & \multicolumn{3}{|c|}{ TBI (Bilateral) } \\
\hline & 2001 & 2009 & 2016 & 2001 & 2009 & 2016 & 2001 & 2009 & 2016 \\
\hline 01 & 1.239 & 1.475 & 2.322 & 1,574 & 2,699 & 3,142 & 0.618 & 0.408 & 0.650 \\
\hline 02 & 0.424 & -4.000 & -5.305 & 0,504 & 0,422 & 0,352 & -0.062 & -0.611 & -0.630 \\
\hline 03 & -0.129 & -0.205 & -0.253 & 0,258 & 0,227 & 0,253 & -0.220 & -0.270 & -0.163 \\
\hline 04 & 5.656 & 2.284 & 1.412 & 2,414 & 2,110 & 1,666 & 0.462 & 0.099 & 0.080 \\
\hline 05 & -0.420 & -0.133 & -0.220 & 0,774 & 0,971 & 0,784 & -0.558 & -0.309 & -0.323 \\
\hline 06 & -1.196 & -1.025 & -0.990 & 0,170 & 0,198 & 0,310 & -0.849 & -0.821 & -0.733 \\
\hline 07 & -2.844 & -2.435 & -2.773 & 0,237 & 0,414 & 0,326 & -0.789 & -0.643 & -0.616 \\
\hline 08 & -4.548 & -2.971 & -3.451 & 0,237 & 0,344 & 0,296 & -0.818 & -0.651 & -0.601 \\
\hline 09 & -0.818 & -0.571 & -0.480 & 0,438 & 0,517 & 1,312 & -0.545 & -0.411 & -0.159 \\
\hline 10 & -0.193 & 3.630 & 4.099 & 0,240 & 1,120 & 1,224 & -0.263 & 0.651 & 0.644 \\
\hline 11 & 1.680 & 1.096 & 0.604 & 3,252 & 2,205 & 1,563 & 0.706 & 0.476 & 0.275 \\
\hline 12 & 3.574 & 2.454 & 0.576 & 2,307 & 1,181 & 0,534 & 0.432 & 0.503 & 0.083 \\
\hline 13 & 0.149 & 0.223 & 0.200 & 1,705 & 2,025 & 1,505 & 0.077 & 0.183 & 0.204 \\
\hline 14 & -0.065 & -0.013 & 0.007 & 0,072 & 0,070 & 0,758 & -0.930 & -0.823 & 0.060 \\
\hline 15 & -0.570 & -0.464 & 0.925 & 0,831 & 0,682 & 1,078 & -0.305 & -0.244 & 0.052 \\
\hline 16 & -0.321 & -0.119 & 0.278 & 0,533 & 0,895 & 0,909 & -0.312 & -0.174 & 0.016 \\
\hline 17 & 1.804 & 0.932 & 1.169 & 2,023 & 1,467 & 1,415 & 0.188 & 0.091 & 0.192 \\
\hline 18 & -0.706 & -0.528 & -0.532 & 1,470 & 1,020 & 1,475 & -0.318 & -0.265 & -0.155 \\
\hline 19 & -0.803 & -0.765 & 0.594 & 1,175 & 1,193 & 1,483 & -0.314 & -0.263 & 0.004 \\
\hline 20 & -0.968 & -1.324 & -1.148 & 0,638 & 0,463 & 0,439 & -0.410 & -0.514 & -0.399 \\
\hline 21 & -1.659 & 0.709 & -0.061 & 1,789 & 2,078 & 1,396 & -0.352 & -0.049 & -0.077 \\
\hline 22 & 2.842 & 1.340 & 0.800 & 1,406 & 1,221 & 1,010 & 0.186 & 0.022 & 0.018 \\
\hline 23 & -2.942 & -1.301 & 0.506 & 0,883 & 0,726 & 1,257 & -0.553 & -0.388 & -0.002 \\
\hline 24 & 0.813 & 1.708 & 3.646 & 1,421 & 2,026 & 3,682 & -0.023 & 0.220 & 0.322 \\
\hline
\end{tabular}

Source: CZSO (2017) 
by exports, we would discover that in the case of volume of trade goods, the Czech Republic has a considerably positive result. However the same cannot be said, if we were to apply the same indicator to the comparison of value of imports and exports. While in the case of volume of realized trade, the coverage of imports by exports is two hundred percent, but in the analysis of coverage of value of imports by exports, the Czech Republic reaches only about ninety percent. However, the coverage percentage is constantly increasing and that is due to an increase in traded mass. The sad reality of Czech agrarian trade is that the success of the Czech agrarian trade lies primarily in the ability of exporting cheaply and minimally processed mass.

The above listed Tab. III provides an overview of competitiveness of Czech agrarian trade, more precisely the disposable comparative advantages in its individual commodity aggregates. The results of the analysis suggests that the Czech agrarian trade has in the recent years significantly strengthened its ability to generate comparative advantages (RCA index), especially on a bilateral basis (LFI index). Nonetheless, the results also suggest that from the perspective of disposable comparative advantages, it is the aggregates with a limited degree of processing and relatively low per kilogram prices that are predominate. In this regard, it is necessary to mention that in the case of Czech agrarian trade, it is not possible to apply the method of results generalization in its entirety. Given the extreme focus of the Czech agrarian trade primarily on the market of EU countries and also given the fact that the Czech agrarian trade is significantly influenced by the Common Agricultural policy of the EU countries, Common Trade policy of the EU countries and furthermore by obligations of the EU to the WTO. It is necessary to analyze the commodity structure of the Czech agrarian trade and its comparative advantages distribution separately in relation to each individual trade partner or in relation to each specific group of trade partners separately. The proof of the different structure of the Czech agrarian trade in relation to different groups of countries can be found in Fig. 1 . This graph gives the overview of the development of
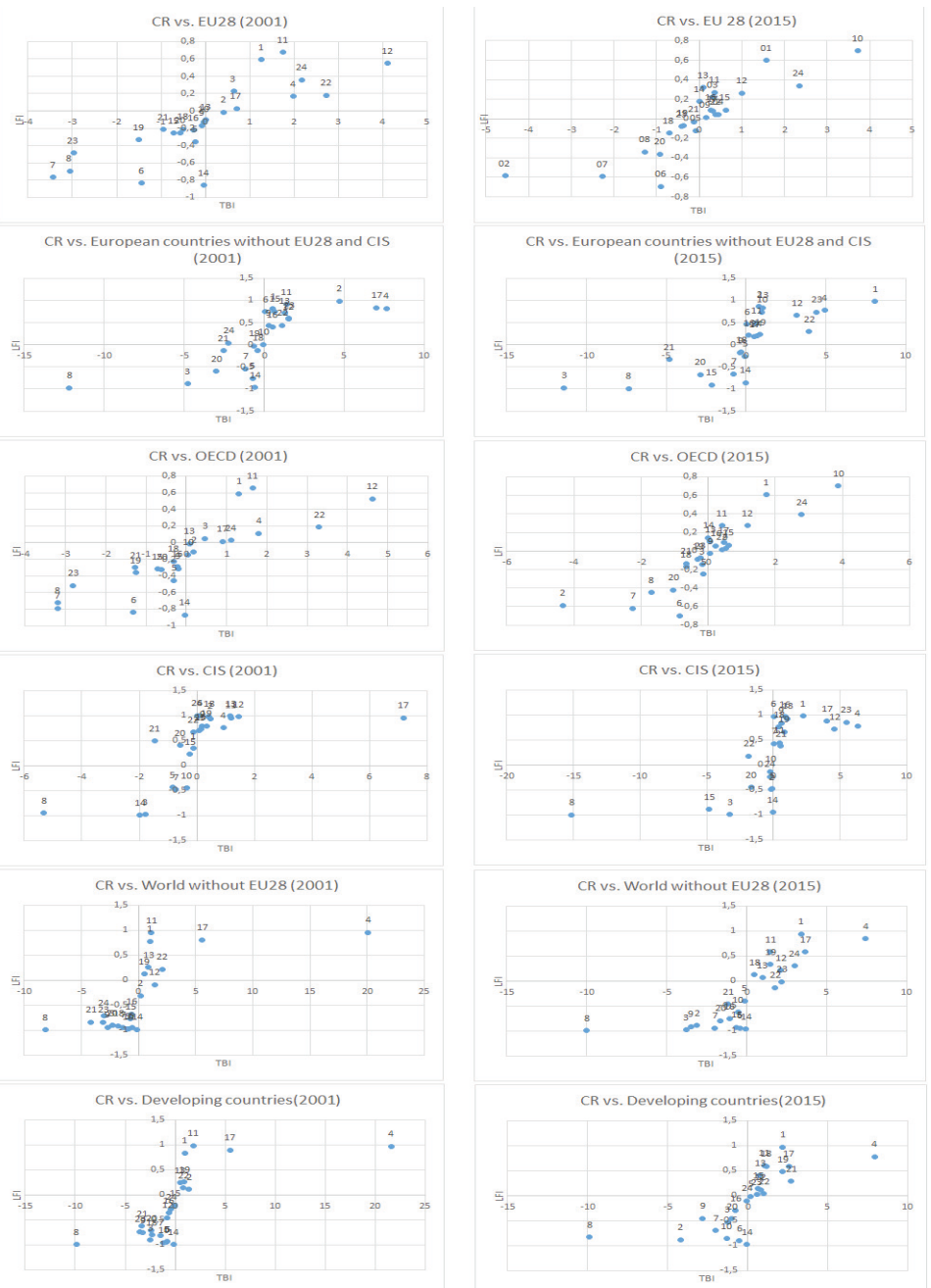

1: Comparison of the development of Czech agrarian exports based on the "product mapping" method from the years 2001 and 2015 Source: own processing, CZSO (2017) 


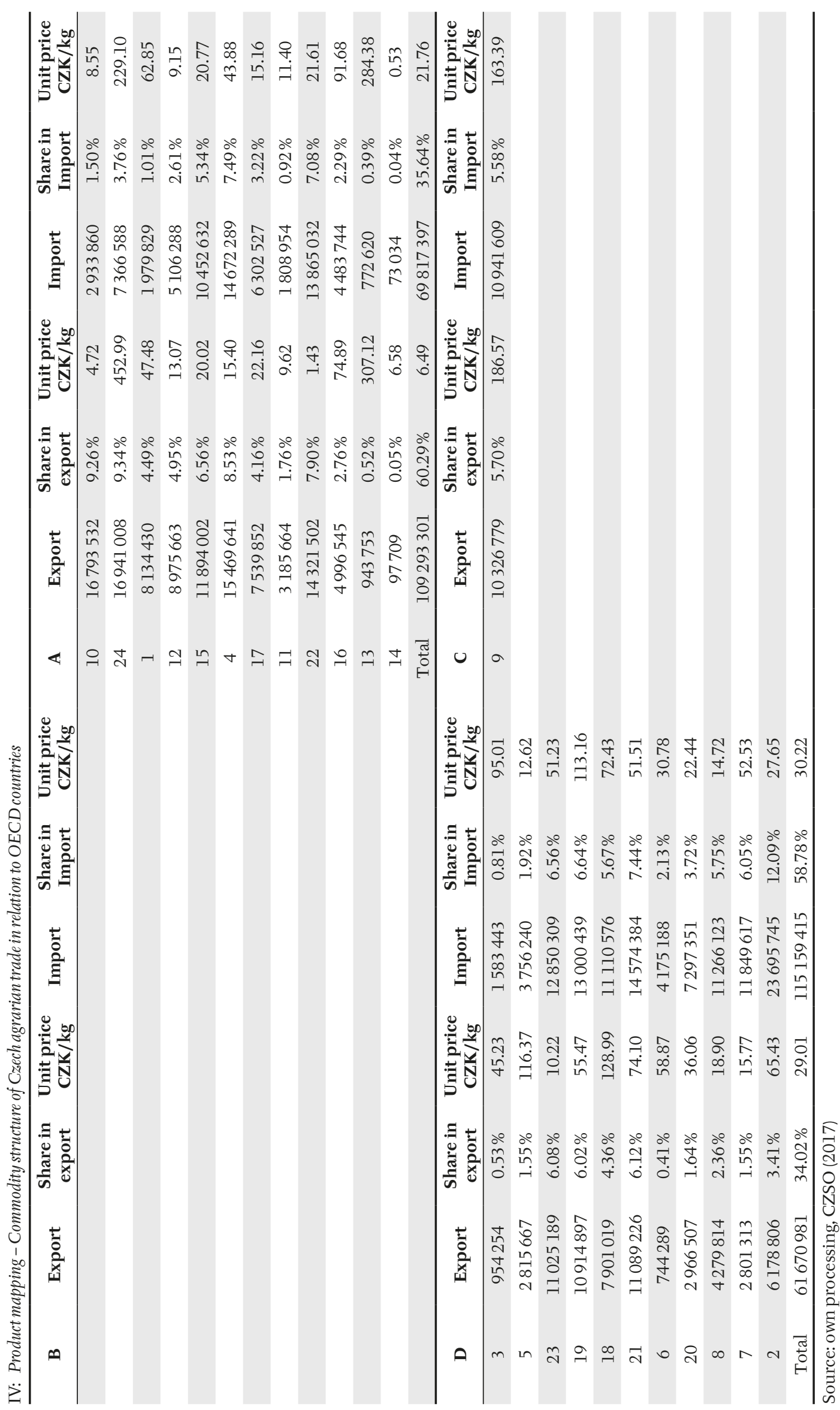


comparative advantages of the Czech agrarian trade in the years 2001 and 2015 in relation to multiple groups of countries. From the figure, it is possible to deduce the extreme heterogeneity of the seemingly homogeneous agrarian trade of the Czech Republic. Therefore, if we want to understand the state of the commodity structure of the agrarian trade (primarily exports), and its comparative advantages in detail, it is necessary to conduct a detailed analysis in relation to selected segments of countries. It is for this reason that in the following subchapters, the analysis of the realized agrarian trade in relation to developed countries (key agrarian trade partner of the Czech Republic) and to developing countries (potentially important partners, which however are at the moment neglected) and also in relation to the former countries of USSS (CIS) and other European countries (i.e. without EU and CIS countries), is conducted separately.

\section{DISCUSSION}

\section{Developed vs. Developing countries}

An interesting viewpoint on the issue of commodity structure of Czech agrarian trade is provided by analysis that is based on a comparison of results of trade between developed and developing countries. In the case of developed countries, the comparative advantages lie in the different position of items within the overall turnover. In addition, the Czech Republic in relation to developing countries during the monitored years experienced more significant changes in the area of value development and structure of the agrarian trade compared to the developed countries, which are the long- term trade partners of the Czech Republic. In the case of the developed countries, the comparative advantages were proved in the case of the following aggregations: CN12, CN22, CN04, CN11, CNO1, CN24, CN17 and CNO3 and CN10, CN24, CNO1, CN12. CN15, CN04, CN17, CN11, $\mathrm{CN} 22, \mathrm{CN} 16, \mathrm{CN} 13$ and $\mathrm{CN} 14$.

In relation to the developing countries comparative advantages included aggregations: CN04, CN17, CN11, CN20, CNO1, CN19, CN22 and CN13, and CN04, CN21, CN17, CN01, CN19, CN18, CN11, CN22, CN12, CN13, CN15 and CN23. The position of the above mentioned aggregates within the commodity structure of the Czech agrarian foreign trade has shifted from about $58 \%$ to about $60 \%$ in the case of exports and $26.6 \%$ to $35.6 \%$ in the case of imports for the developed countries during the monitored years. In the case of developing countries, the share of the above aggregates has changed from about $78 \%$ to about $75 \%$ and for exports from $8 \%$ to about $28 \%$ for imports.

It is contradictory that, in relation to the developing countries, the Czech Republic achieves significantly better export/import price ratios than in the case of developed countries. While in the case of developed countries, prices of exports and imports decreased from CZK $14.56 / \mathrm{kg}$ to CZK $9.54 / \mathrm{kg}$ and from CZK $21.6 / \mathrm{kg}$ to CZK $27.65 / \mathrm{kg}$ between the monitored years. For developing countries, the results are as follows: In the case of exports, prices rose from CZK $27.7 / \mathrm{kg}$ to CZK $36 / \mathrm{kg}$ and in the case of imports from CZK $25.25 / \mathrm{kg}$ to CZK $38.16 / \mathrm{kg}$. There are also significant differences when comparing per kilogram export and import prices for developed countries and developing countries, in particular with an emphasis on the aggregation group within Segment A and Segment D. For segment A, the kilogram export prices and/or imports to advanced countries shifted during the monitored years from CZK $13.15 / \mathrm{kg}$ to CZK $6.49 / \mathrm{kg}$ and from CZK $20.43 / \mathrm{kg}$ to CZK $21.8 / \mathrm{kg}$, in relation to the developing countries, the following shifts were recorded: from CZK $26.22 / \mathrm{kg}$ to $33.60 \mathrm{CZK} / \mathrm{kg}$ for exports from $36.50 \mathrm{CZK} / \mathrm{kg}$ to $29.62 \mathrm{CZK} / \mathrm{kg}$. From the monitored group of aggregates, it also follows that, in the case of developed countries, the value of Czech agrarian exports was "driven" primarily by an increase in export volumes from 1.7 billion tons to about 16.8 billion tons. While in the case of exports to developing countries, growth in value was driven by a combination of growth in price and volume of exports, which grew from CZK 280 thousand tons to 465 thousand tons. Concerning the value of closed export/import contracts under Group A, there are the following differences between developed and developing countries: In relation to developed countries, the Czech Republic recorded an increase in exports from CZK 23 billion to CZK 109 billion and an increase in imports from around CZK 14.7 billion to about CZK 70 billion. In the case of developing countries, the growth of export and import values was much less significant during the monitored period, from around CZK 7.3 billion to CZK 15.6 billion, or CZK 1.1 billion to CZK 7 billion.

In the case of segment $\mathrm{D}$, there are the following differences in relation to developed countries and developing countries: The realized export or import prices have changed less significantly over the monitored years than compared to segment A. In the case of these countries, the prices of exports and imports have increased from CZK 18/kg to CZK $29 / \mathrm{kg}$ and from CZK $22.5 / \mathrm{kg}$ to CZK $30.2 / \mathrm{kg}$. The volume of exports and imports increased over the years from 787 thousand tonnes to about 2.1 million tonnes and 1.6 million tonnes to 3.8 million tonnes. In the case of developing country partners, export prices grew from CZK $34.4 / \mathrm{kg}$ to more than CZK 75/kg and from CZK 24.6/kg to CZK $42 / \mathrm{kg}$. In the case of volume, the development was completely different between exports and imports. In the case of developed countries the volume of exports remained unchanged and remained at the level of 61 thousand tonnes, the volume of imports dropped from 522 thousand. tons to 424 thousand. The value of closed export and import contracts grew from CZK 14 billion to CZK 61 


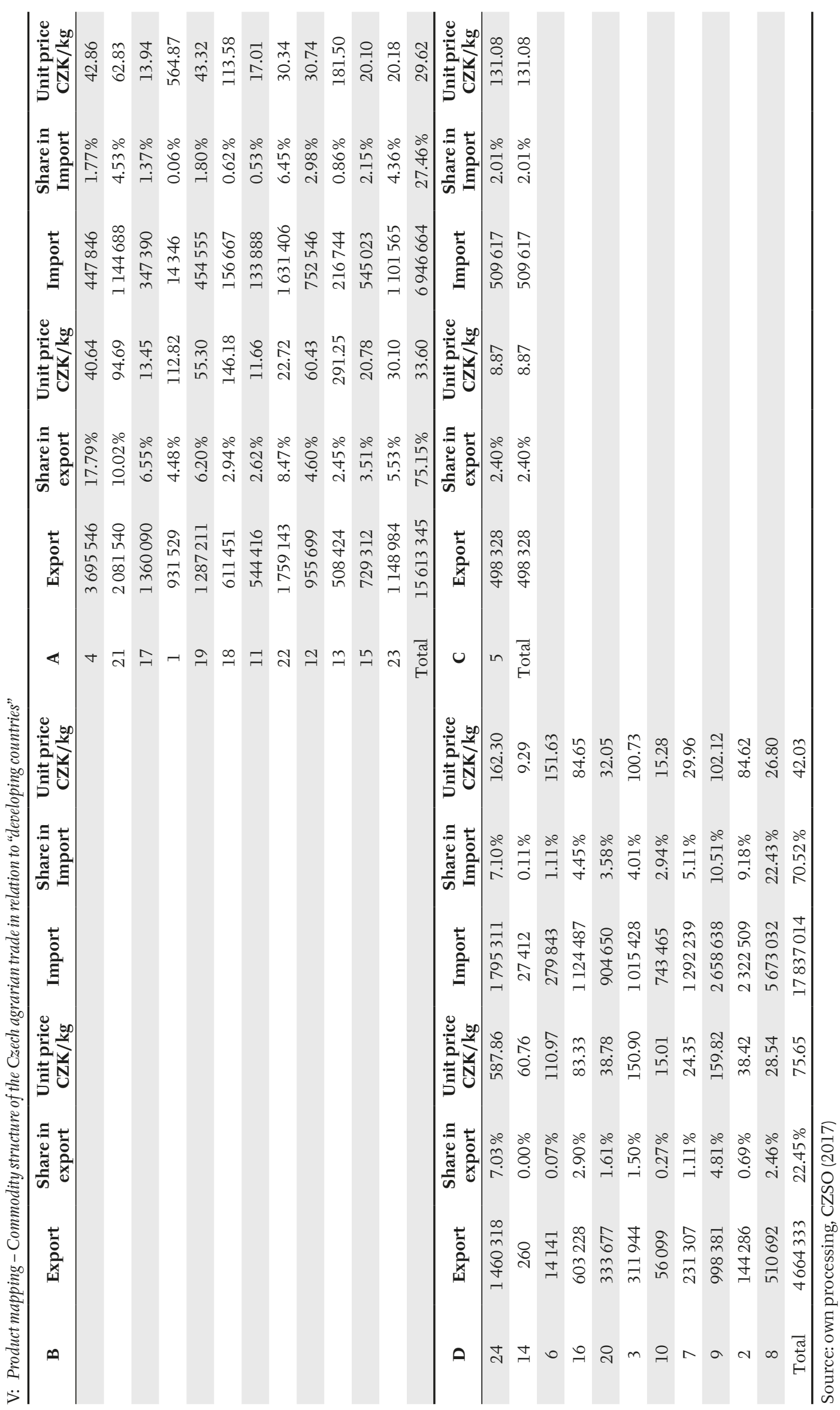




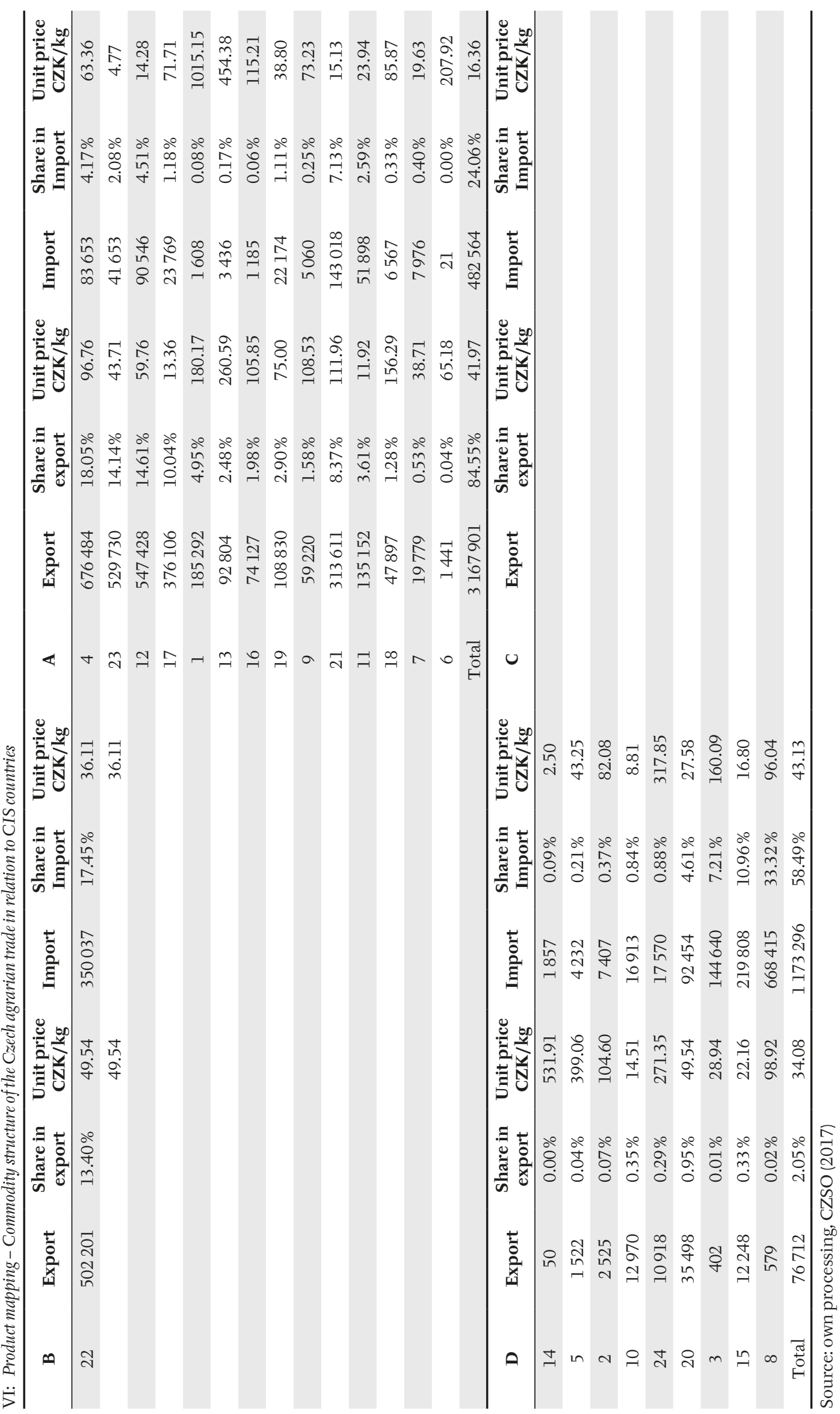




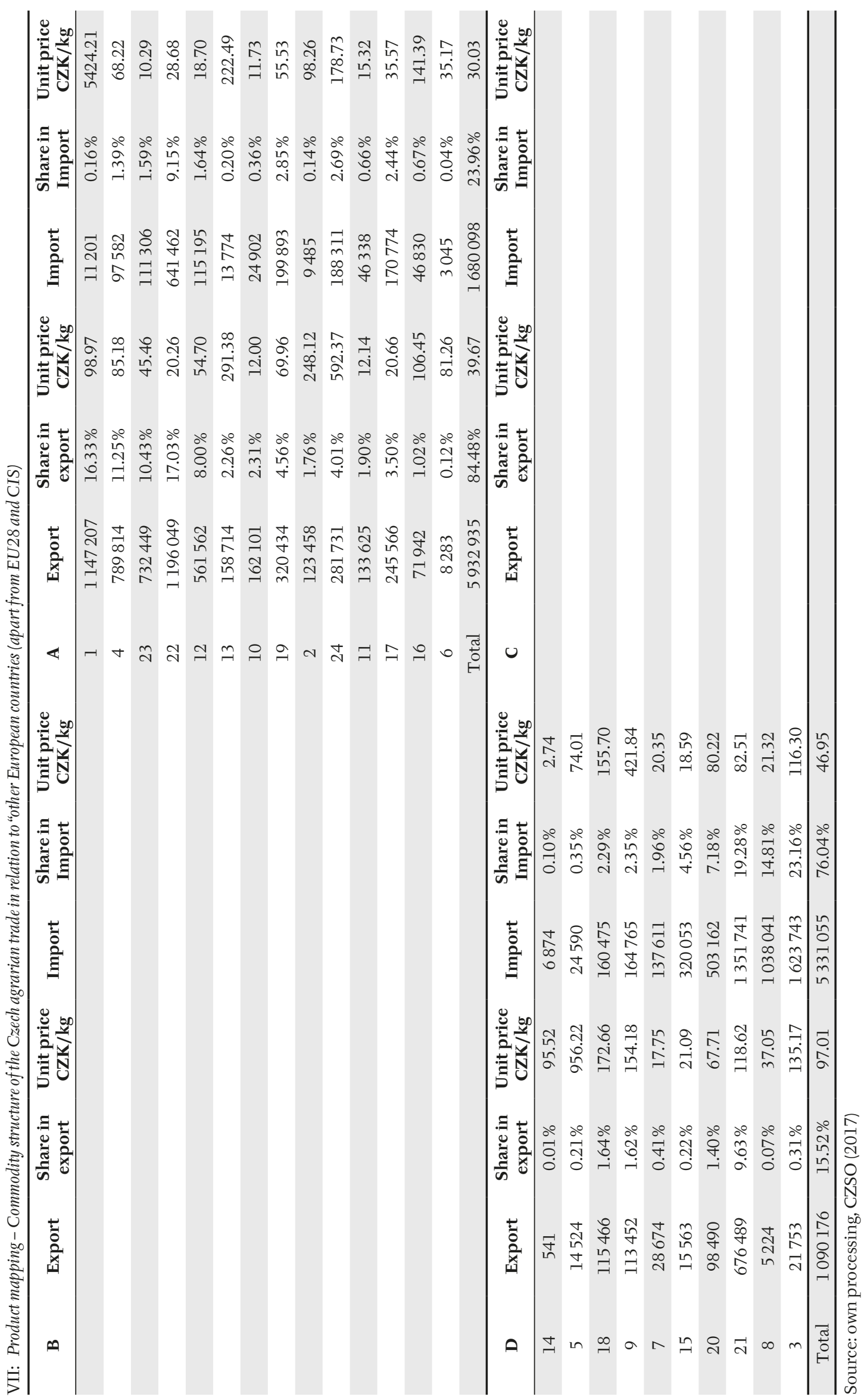


billion, from CZK 37 billion to CZK 115 billion for developed countries. This was much more dynamic than in the case of developing countries where exports and imports grew within Group D from CZK 2 billion to CZK 4.6 billion and from CZK 13 billion to CZK 18 billion.

\section{Other European countries and countries of CIS}

From the perspective of the territorial structure of agrarian trade, the Czech Republic has primarily focused on European countries and countries of the former Soviet Union (among which Russia, Ukraine and Belarus-the European countries dominate as trading partners). In the case of agrarian trade, the share of European countries increased in the monitored period from $83 \%$ to $93 \%$. Of course, the dominant share from these percentages was represented by previously mentioned EU28 countries. Nonetheless, the share of CIS, respectively other European countries was not negligible and during the monitored period remained at around $1.5 \%$ and $3 \%$.

It is clear that both groups of countries represent destinations where the Czech Republic is able to offer goods with higher added value and higher per kilogram prices. Where, in relation to CIS countries, export prices increased from CZK 18/kg to CZK $37 / \mathrm{kg}$ between the monitored years and, for other European countries, from CZK 25.2/ kg to CZK $44 / \mathrm{kg}$. The ratio of export price to import price is then much more favorable than in relation to EU28 countries. Import prices have shifted from CZK $18.6 / \mathrm{kg}$ to CZK $30.2 / \mathrm{kg}$ for CIS countries and from CZK 34.24/kg to CZK 41.4/kg for the other European countries. In relation to other European countries, the comparative advantages of Czech agrarian trade were based on the following aggregations: CN04, CN17, CN11, CN23, CN22, CN15, CNO1, CN16, CN09 and CNO6 and 01, CN04, CN23, CN22, CN12, CN13, CN10, CN19, CNO2, CN24, CN11, CN17, CN16 and CN06. From this it is suggested that the structure of aggregations with comparative advantages has not changed very much. The average per kilogram price of exports and imports within the category, with comparative advantage reached in the monitored period increased from approx. 21.8 CZK to approx. $40 \mathrm{CZK}$ and from $17 \mathrm{CZK}$ to $30 \mathrm{CZK}$. This suggests that mainly the growth dynamics of export prices were different from the average and the growth of value of exports was realized mainly through an increase of unit price and not through an increase in the volume of traded products like in the case of EU28 countries. During the monitored period, the trade mass of exports and imports within the above mentioned category increased from 89 thousand tonnes to approx. 150 thousand tonnes and from approx. 17 thousand tonnes to approx. 56 thousand tonnes. The value of exports and imports had during the monitored years increased from approx. 2 billion CZK to approx. 6 billion CZK and from 285 million CZK to 1.7 billion CZK.

In the case of other aggregations, which the Czech Republic does not have comparative advantages over other European countries, the trade realized within this group of goods (without proven comparative advantages) grew during the monitored period. The growth is as follows: For exports, CZK 310 million to about CZK 1.1 billion and for imports from CZK 1.2 billion to more than 5, 3 billion CZK. The volume of closed contracts increased from approximately 12.6 thousand. tons to 11.24 ths. Tonnes, for exports, and 33 thousand tonnes to approximately 114 thousand. tonnes in the case of imports. Per kilogram prices of exports and imports within this group of aggregations also experienced very significant shifts from about CZK 25 to CZK 97 in the case of exports and from about CZK 36 to about CZK 47 in the case of imports. In relation to the CIS countries the comparative advantages have been existing in the case of the following aggregations: CN17, CN12, CN11, CN13, CN14, CN11, CN16, CN23, CN09, CN16, CN23, CN24, CN23, CN13, CN16, CN19, CN09, CN21, CN11, CN18, CNO7 and CN06. This is the same as in the case of other European countries, CIS countries have only experienced marginal changes over the years in terms of the number and nature of items with comparative advantages. Nonetheless, the development in unit prices, volume and value of closed contracts have seen significant changes over the years.

The average per kilogram price of exports and imports within the category with comparative advantages reached an increase of approx. CZK 17.5 to approx. CZK 42 and CZK 9.4 to CZK 16.4. This shows that, as in the case of other European countries and the CIS countries, the dynamics of export price growth differed from the average, and the growth in export value was mainly driven by unit price growth rather than by growth in the volume of traded goods, as it is in relation to the EU28 countries. During the monitored years, the traded mass of exports (despite the growth of the value of the contracts closed) dropped within the above-specified category (mainly due to the sanctions imposed by Russia on exports from EU28 countries). On the contrary, in the case of imports, the imported material increased from approx. 10 thousand tons to approx. 30 thousand tonnes. The value of exports and imports over the years has grown from approximately CZK 1.366 billion to about 3.2 billion CZK and from CZK 94 million to about CZK 483 million. In the case of other aggregations (not mentioned above), the Czech Republic generally does not have comparative advantages against the CIS countries. The trade realized within this group of goods (without proven comparative advantages) has declined over the years from CZK 135 million to about CZK 77 million in the case of exports (this is a clear effect of the sanctions that have severely 
influenced the trade within the CNO2 and CNO8 aggregations). On the other hand, the value of imports increased from approximately CZK 168 million to about CZK 1.2 billion. The volume of closed contracts decreased in the case of exports from approx. 3 thousand tons to 2.25 hs. tonnes, while in the case of imports, it grew from approx. 4.6 thousand tons to about 27 thousand tons. Per kilogram prices of exports and imports within this group of aggregates also recorded very significant shifts from CZK 44.2 to CZK 34.1 in the case of exports (the reduction is due to the sanctions imposed by the Russian Federation on European Union or Czech exports to Russia) and from approx. 36.2 CZK to about 43.1 CZK for imports.

\section{CONCLUSION}

From the results of the conducted analysis, it is possible to carry out the following discussion which is best summarized in the following Tab. VIII. Tab. VIII provides a certain overview of the development of the Czech Agrarian trade in relation to selected groups of countries. The results suggest that the agrarian trade performs very differently in relation to individual groups of countries. The Czech agrarian trade is developing very gradually, primarily in relation to developed countries of the world. In this regard it is worth mentioning that the constantly improving characteristics of the Czech agrarian trade in relation to EU28 countries. In relation to developing countries the Czech agrarian trade is deteriorating. A specific development of the Czech agrarian trade was recorded also in relation to CIS countries. Towards these countries, the Czech Republic has at its disposal a very competitive commodity structure based primarily on the export of goods with higher value added and relatively high per kilogram prices. The positive development in relation to these countries is supported by the positive values of indices of imports by exports. However, the trade in relation to these countries is currently being negatively influenced by the mutual sanctions imposed because of the political crisis in Ukraine and Annexation of Crimea, by Russia. An important role is also played in the specific situation of the Russian market (Kharcheva, 2016; Kontsevaya, 2016). Important trade partners of the Czech Republic are also the "other European countries“ (i.e. non EU and CIS countries). With these countries, the Czech Republic is currently able to maintain a competitive goods structure based primarily on products with higher value added and higher per kilogram prices (the positive state in this regard is supported primarily by the positive values of coverage indices of imports by exports in relation to unit prices and overall value of realized transactions). If in the end we compare the development of the commodity structure and the distribution of the comparative

VIII: Coverage of imports by exports (balance of overall Czech agrarian trade)

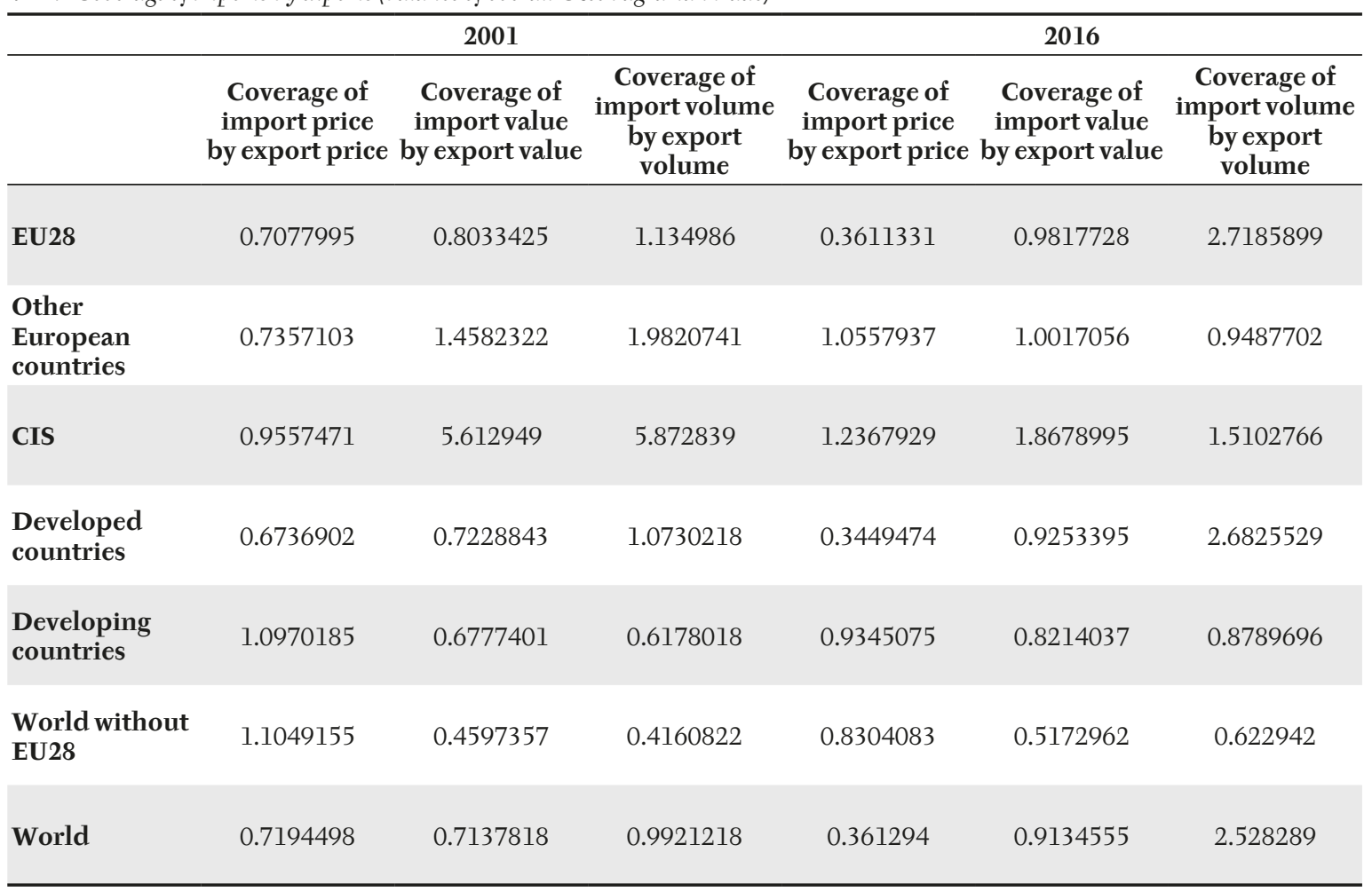

Source: own processing, CZSO (2017) 
advantages in the case of developed countries on one side and developing countries on the other, we determine that the Czech agrarian trade is two-sided. One of those sides is relatively developed and that is paradoxically the one in relation to developing countries. The other side is in relation to developed countries, who make up the main trade partners and it is relatively underdeveloped. While in relation to the developing countries, the structure of the agrarian trade is based primarily on items with a higher degree of processing and higher per kilogram prices, in relation to developed countries, it is the exact opposite. It is a contradiction that from this perspective, the Czech Republic is trying to push through primarily in the developed markets and its effort in the developing markets is relatively minimalistic and from the point of view of public sector support is nearly negligible. Where at the same time, it is the developing countries of the world, which will in the future represent the key markets of the agrarian and food production.

\section{Acknowledgement}

This paper has been made possible by the generous financial support of IGA, FEM, CULS Prague. Grant number 20171024-The analysis of Czech agrarian trade commodity structure.

\section{REFERENCES}

BALASSA, B. 1965. Trade liberalization and "revealed" comparative advantage. The Manchester School of Economics and Social Studies, 33(2) 99-123.

BALASSA, B. 1977. Revealed' Comparative Advantage Revisited. The Manchester School of Economics and Social Studies, 45(4): 327-344.

BAŠEK, V., KRAUS, J. (2009). Czech foreign agricultural trade after joining the European Union. AGRICULTURAL ECONOMICS Volume 55, Issue 12, 2009, Pages 583-595. ISSN: 0139-570X

BURIANOVA, J. 2011. Agrarian foreign trade of the Czech Republic in the period of 2004-2008, competitiveness of commodities. Acta Universitatis Agriculturae et Silviculturae Mendelianae Brunensis, 59(4): 37-42.

BURIANOVA, J. 2011. Effect of the 2008-2009 economic crisis on the results of agricultural foreign trade of the Czech Republic. Agricultural Economics, 57(5): 226-231.

BURIANOVA, J. 2012. The competitiveness of agricultural foreign trade commodities of the CR assessed by way of the Lafay Index. Agris On-line Papers in Economics and Informatics, 4(4): 27-36.

BURIANOVA, J. and BELOVA, A. 2012. The competitiveness of agricultural foreign trade commodities of the CR assessed by way of the Lafay Index. Agris On-line Papers in Economics and Informatics, 4(4): 27-36.

FERTÕ, I. 2008. The evolution of agri-food trade patterns in Central European countries. Post-Communist Economies, 20(1): 1-10.

JÁMBOR, A. 2014. Determinants of intra-industry agri-food trade in the Visegrad countries. Acta Alimentaria, 43(2): 246-253.

KANCS, D. and CIAIAN, P. 2010. Factor content of bilateral trade: The role of firm heterogeneity and transaction costs. Agricultural Economics, 41(3-4): 305-317.

KHARCHEVA, I., KONTSEVAYA, S. and MAITAH, M. 2016. Analysis of Manpower Resources Utilization in Agricultural Organizations of the Russian Federation. In: Proceedings of the 2016 International Conference "ECONOMIC SCIENCE FOR RURAL DEVELOPMENT" No 42. Jelgava, LLU ESAF, 21-22 April 2016, pp. 244-249.

KONTSEVAYA, St., ALBOROV, R., KONTSEVAYA, Sv. et al. 2016. Estimation of Current Status of Internal Economic Control in Russian Agriculture. In: Proceedings of the International Conference «Economic Science for Rural Development No. 43». Jelgava: Latvia University of Agriculture, pp. 291-296.

LAFAY, G. 199. The measurement of revealed comparative advantages. In: DAGENAIS, M. G. and MUET, P. A. (Eds.). International Trade Modeling. London: Chapman \& Hill, pp. 209-234.

MEZERA, J. and POHLOVA, K. 2014. Analysis of development of Czech foreign trade in foods and beverages. Agris On-line Papers in Economics and Informatics, 6(4): 121-131.

PRESOVÁ, R., TVRDOŇ, O. and ŽIVĚLOVÁ, A. 2008. Importance of intrastat in EU intra-Communtty trade. Acta Universitatis Agriculturae et Silviculturae Mendelianae Brunensis, 56(3): 175-86.

SMUTKA, L., STEININGER, M., MAITAH, M. et al. 2015. The Czech agrarian foreign trade - ten years after the EU accession. In: $24^{\text {th }}$ International Scientific Conference on Agrarian Perspectives - Global Agribusiness and the Rural Economy. Prague, Sept. 16-18, 2015, pp. 385-392.

SVATOS, M. 2008. Selected trends forming European agriculture. Agricultural Economics (Zemédélská ekonomika), 54(3): 93-101.

SVATOS, M., MAITAH, M. and BELOVA, A. 2013. World sugar market-basic development trends and tendencies. Agris On-line Papers in Economics and Informatics, 5(2): 73-88.

VOZAROVA, I. K., KOTULIC, R. and SIRA, E. 2015. V4 countries' agricultural sector evaluation in terms of competitive advantage. Economic Annals-XXI, 5-6: 60-63. 
WIDODO, T. 2009. Comparative Advantage: Theory, Empirical Measures and Case Studies. Review of Economic and Business Studies, 4: 57-82.

ZAGHINI, A. 2003. Trade advantages and specialization dynamics in acceding countries. Working paper № 249. Frankfurt am Main, Germany: European central bank, pp. 4-15. 